\title{
THE PATRILINEAL DISCOURSE OF ENLIGHTENMENT: READING FOUCAULT READING KANT
}

Odd confluences made this study. I first read Foucault's enlightenment essay' while immersed in feminist critiques of Kant. Shortly thereafter, Thomas McCarthy visited Richmond and mentioned that he had the French original of the essay. When I later requested this, he sent me instead a copy of a Magazine Litteraire interview with Foucault about the essay, said it was the only French version that he was aware of, and suggested contacting James Schmidt at Boston University. I contacted James Schmidt and received in return a copy of his own most recent piece on Foucault and an apology for having once been in possession of the French original and having lost it. He suggested contacting the editor of the Foucault Reader, Paul Rabinow. I contacted Paul Rabinow, who told me that all of Foucault's texts were to be found at the Bibliotheque Saulchoir in Paris, which, unfortunately, does not make copies, and that I would have to go there myself.

Tempted to approach the dean for an urgent travel supplement, I decided instead to exploredomestic alternatives and call the translatorof the essay, Catherine Porter, at SUNY-Cortland. I also settled on an interim project title of "Whereis What is Enlightenment?" The operator, whose name was also "SUNY-Cortland, "said that there was no Catherine Porter on the faculty. I began to lower the receiver in an act of resigned closure, when she hastened, "No, wait, Catherine ... sure, she got married ...changed her name to Lewis. I'll connect you." A secretary then answered whose name was "International Communications and Culture." She informed me that Catherine Porter Lewis was on sabbatical in Paris and gave me an address. $I$ wrote her in Paris, and she kindly replied that the original French manuscript was locked in her office back in Cortland, and she would not be returningfor quite some time. I was somewhat encouraged but nonetheless resigned to a long wait, when, two weeks later, a manila envelope arrived from SUNY-Cortland that contained the French manuscript and a pleasant memo from the departmental secretaryannouncing the discovery and signed simply "Angie."

\footnotetext{
'Michel Foucault, "What is Enlightenment?", in The Foucault Reader, ed. Paul Rabinow (New York: Pantheon, 1984).
} 
I am reminded of Robin Lakoff's ${ }^{2}$ observation, verifiable in most graduate departments, that men have last but women first names. As it turned out, the successful path was not a hierarchy, but a horizontal network, unnamed and never fully articulated, of subjects with nominal fluidity, with metonyms, with other's or first or no names, sharing information within private spheres. The vertical path of descent from the father, of patronyms publicly known, fully and individually articulated, yielded but dissimulation.

Perhaps a different kind of archaeology would illuminate an unnaming discourse of power, of other muted voices, of disempowerment that is itself never fully spoken, and whose actors are never fully articulate(d).

The English translation of Foucault's unpublished French manuscript ${ }^{3}$ addressing Kant's statement on enlightenment appeared in 1984,200 years after the publication of Kant's essay. Foucault meant to entitle his essay as Kant did, but instead he gave it the interested and partially correspondent title What is Enlightenment? This is only a partial correspondence, because the full title of Kant's essay is Beantwortung der Frage:Was ist Aufklärung?' Foucault's title suppresses the fact that Kant's essay is not framed as a question, but as a definitive answer. This is present in the perfectiveness of the initial substantive; it is not an Antwort but a Beantwortung, not a simple response to the question, but the perfective and definitive resolution of the question itself. This is underscored by the interposition of a colon, which acts to objectify and organize the answer, and more forcefully by the fact that the text itself begins with a definition. Foucault's title is an allusion and not an identification, a partial reading that enables Foucault to frame Kant's answer as an incipient instance of problematization and difference. He

\footnotetext{
${ }^{2}$ Robin Lakoff, Language and Woman's Place (New York: Harper \& Rowe, 1989).

${ }^{3}$ Foucault, "What is Enlightenment?" (unpublished French manuscript). I am deeply and, here, seriously grateful to Catherine Porter Lewis and to Angie for providing me with a copy of the manuscript.

'Curiously, the tide of the French manuscript is hand-inscripted in English.

'Immanuel Kant, Beantwortung der Frage: Was ist Aufklärung? in Kants Werke. Akademie-Textausgabe, 9 Bände (Berlin: Waiter de Gruyter, 1968), 8:33-42. All subsequent passages from Kant are referred to only by volume and page number.
} 
claims that, with Kant's text, "entre discrètement dans l'histoire de la pensée une question à laquelle la philosophie moderne n'a pas été capable de répondre, mais dont elle n'est jamais parvenue à se débarrasser. ${ }^{n 6} \mathrm{He}$ sees Kant's text as "la question lancée, voici deux siècles, avec tant d'imprudence: Was ist Aufklärung?"7

The use of discretement supplies meanings of nuance and sensitivity to Kant's gesture. This is supposed to be a discrete and sophisticated disabling of philosophical discourse. The use of the term se débarrasser, which conventionally means to get rid of, is root related with embarrassant, which carries meanings similar to the German peinlich, and evokes the notion of imprudence. Thus Kant is supposed to have made philosophical discourse uncomfortable with a peinliche Frage. This is the fresh (male) kid, who individually and imprudently asks an embarrassing question.

Foucault then represents German and Jewish traditions as hierarchically interconnected in a grand metanarrative. The reader is told that, because Moses Mendelssohn and Kant both addressed the enlightenment question two months apart in the journal Berlinische Monatsschrift, "L'Aufklärung allemande et l'Haskala juive reconnaissent qu'ils appartiennent à la même histoire," even though the texts are reciprocally unaware of each other's existence. Nonetheless, their appearance in the same journal is, for Foucault, "une manière d'annoncer l'acceptation d'un destin commun, dont on sait à quel drame il devait mener. ${ }^{8}$ This specious and interested narrative is also a forced dovetailing of the German and Jewish traditions according to events that were to occur one and a half centuries later. This oblique allusion to the holocaust is a euphemizing thereof, for the holocaust is signed both as drama and as an histoire,--a story or fiction. Foucault's procedure works to evoke images that serve to empower the representation of Kant and help situate the essay as an ominous occurrence at the incipience of a great historical drama. Not only is the text a beacon for a movement; it is also the beginning of modernity.

The phrase "annoncer l'acceptation d'un destin commun" also brings up fatalistic images of Germanic tragic heroism, of the

${ }^{6} I b i d .$, p. 1.

'Ibid., p. 2.

IIbid., p. 2. 
Schicksalsheld who stoically accepts his own fate, a fate that is often an embodiment and indication of a macrocosmic cultural change. This theme resonates as a contrabass for the fiction of the philosopher at the crossroads of history, and it resonates deeply, as the Leitmotiv of distant thunder. In addition, the notion of agency is strengthened by the use of the term annoncer, which acts to transform a simple juxtaposition of discrete texts into a conscious act of choral proclamation.

Kant's text itself is explicitly hierarchical, in that it liberates the German bourgeois philosopher to unfettered public debate while confining the functionary to a state of mechanical servitude. Hierarchical ranking is also evident in Foucault's juxtaposition of the German and Jewish intellectual traditions, to which his discourse does not grant parity: the German tradition is lexically privileged. The text pairs the "mouvement philosophique allemand" with "laculture juive, "la pensée allemande" with "la culture juive," and "la philosophie allemande" with "la pensée juive." In these doublets, the German tradition receives the intellectually more privileged term, since philosophy outranks thought, thought is nobler than culture.

Foucault then proceeds to distinguish previous attempts by philosophy to reflect on its own present according to three categories. The present either belongs to a distinct era of the world (as in Plato), heralds a forthcoming event (as in Augustine), or is seen as the point of transition to a new world (as in Vico). ${ }^{10}$ Kant's reflection on the present is summed up in a statement, which can be viewed as a microcosm of Foucault's misreading: "Or la manière dont Kant pose la question est tout à fait différente ... presqu'entièrement négative. " 11 Here Foucault transforms Kantian closure into a synchronic and Saussurian indeterminacy: "la question concerne la pure actualité ...il cherche une difference. "12 The interjection of the term différence, the observation that Kant's definition is framed negatively as an Ausgang, and the projection of synchrony into the text all combine to situate the essay at the nascence of (post)modernity.

Close reading of the text, however, reveals that Kant's reflection

'Ibid., p. 2.

${ }^{10}$ Ibid., p. 3.

"Ibid., pp. 3-4.

${ }^{12}$ Ibid., p. 4. 
on the present easily falls into each of the three categories that Foucault attempts to set in contradistinction to Kant: the epochal, heraldic, and transitional. This is evident in the following passage from Kant:

Leben wir jetzt in einem aufgeklărten Zeitalter? ...Nein, aber wohl in einem Zeitalter der Aufklărung ...davon haben wir deutliche Anzeigen ...das Zeitalter der Aufklărung oder das Jahrhundert Friedrichs.

Here the present is clearly a separate (monarchial) epoch, an age of enlightenment that is in transitional progression toward an enlightened age, and for which there are clear Anzeigen, indicators of future development. In addition, Kant states "daß das Feld geöffnet wird" for humans to develop in the direction of enlightenment. This description is at once epochal, portentous, and transitional and resists Foucault's synchronic and differential reading.

Foucault rightly observes that the "Aufklärung est un processus qui nous dégage de l'état de 'minorité." ${ }^{13}$ This is a reference to the initial definition "Aufklärung ist der Ausgang des Menschen aus seiner sebstverschuldeten Unmündigkeit" (8:35). Here Foucault moves toward a linguistic appreciation of Kant's concept of enlightenment but does not go beyond the surperficial aspects. He observes the crucial opposition between Aufklärung and Unmündigkeit and translates the latter as minorité. This glosses over the overdetermination of the term Unmindigkeit, which is a substantivization of the adjective unmündig. It conveys more the condition of being a minor (non-adulthood) rather than the quality of immaturity itself, which is more securely located in the semantic field of unreif or unerwachsen. In its radical form the term plays upon the resonances of Mund and represents minors as those who are in a condition of not being able to speak for themselves. In the enlightenment essay, Kant directly represents the state of unenlightenment exclusively by lexical choices that are derivatives of the root Mund, which appears in various forms twenty times in the text, not only in the terms unmindig/Unmilndigkeit, but also in the representation of the caretakers of the unenlightened as Vormünder, those who speak for and before the unenlightened. The Vormünder are those upon whom one is (orally) dependent for the articulation of thought.

The most striking aspect of Kant's description of unenlightenment via oral metaphors is that it frames the discussion of the public sphere.

\footnotetext{
${ }^{13}$ Ibid., p. 4.
} 
During this discussion, which privileges the unbound male scholar, references to the oral are entirely absent. They cease as the discussion begins and reappear as the discussion ends. Indeed, Kant characterizes the public use of reason as performed by a "Gelehrter ...vor dem ganzen Publikum der Leserwelt" (8:37). The latter represents the public sphere as the sphere of the reading public. This is not the public but the published use of reason in a sphere that is determined by considerations of gender.

Jane Flax's ${ }^{14}$ recent reading of "What is Enlightenment?", highlights the "gendered geography"15 and "gendered dichotomies"16 in Kant's construction of the public and private spheres. Flax holds that the private sphere is associated with the woman's world, with domesticity and child-rearing:

\begin{abstract}
The power of domestication (woman) is so great that its overcoming requires the counterforce of an entirely different sphere: the public world ... in this account autonomy is understood as the opposite of connection: walking alone, not holding someone's hand. Good guardians enable us to grow up and leave home/childhood, but to do so they must have access to the public world. ${ }^{17}$
\end{abstract}

Thus Flax sees the public sphere as the domain of escape from the maternal-familial complex. Flax's reading is supported by the semantic field of the term privat, which also contains meanings of domesticity, intimacy, and sexuality. These connotations are supported by Kant's application of the term häuslich to this sphere. Thus the private sphere has personal, emotional, and sexual connotations - attributes that are excluded from the sphere of reason and enlightenment. The enlightened male subject is thus located in a position that is independent of and superordinate to the domestic/maternal/feminine. It is a position that effects a monosexual dialogue, a forum of unbinding and coincidental communication among autonomous male subjects. In this state, one "genießt einer uneingeschränkten Freiheit, sich seiner eigenen Vernunft zu

\footnotetext{
14Jane Flax, Disputed Subjects: Essays on Psychoanalysis, Politics, and Philosophy (New York: Routledge, 1993).

19lbid., p. 75.

${ }^{16}$ Ibid., p. 76.

${ }^{17}$ Ibid., p. 77.
} 
bedienen und in seiner eigenen Person zu sprechen" (8:37).

The private sphere, on the other hand, is represented as "sehr enge eingeschränkt" (8:37) as a Mechanism and a Maschine, and as consisting of passive Glieder--a term that can denote members, bodily parts, family members, and sexual organs; these are meanings that resonate throughout this text.

If Kant's essay has, indeed, problematized philosophical discourse, it has done so by foregrounding the paradoxical dyad of the public and private uses of reason. Similarly, Foucault wonders "comment l'audace de savoir peut s'exercer en plein jour, tandis que les individus obéiront aussi exactement que possible?"18 This paradox serves to suspend discourse, leaving the question unresolved and maintaining the isolation of the published sphere of scholars. In the dyad of scholar/functionary, it is the scholar who occupies the privileged position of social and political critique. The scholar functions en plein jour, in a space of openness, light, and freedom that contrasts with the confined and dark spaces of the private sphere. Oddly, Foucault leaves unread the class conscious power moves in this dyad, especially when he reads räsonieren as "un usage de la raison dans laquelle celle-ci n'a pas d'autre fin qu'elle-même; 'räsonieren', c'est raisonner pour raisonner. ${ }^{19}$ This avoidance strengthens his synchronic and differential reading of the text but ignores the exclusionary, masculinist, and elitist elements, which culminate in the final laudation of Frederick the Great, who, by virtue of his absolute and military authority, can declare "was ein Freistaat nicht wagen darf: räsoniert, so viel ihr wollt und worüber ihr wollt, nur gehorcht!" (8:41).

Foucault then attempts to offer a closer reading of Kant's term Menschheit, which he uses in its German form and translates as humanite. ${ }^{20}$ He then asks whether this is humanité in the sense of humankind or humanness. The ambiguity is present in French as well as in English, since both humanity and humanité are double-entendres; but not in German, which clearly supplies the term Menschlichkeit to access the semantic field of humanness. The question that Foucault failed to ask is to what extent the term Menschheit opposes mankind to humankind to the exclusion of womankind. One could also inquire as to the inclusivity

\footnotetext{
${ }^{18}$ Foucault, p. 8.

19Ibid., p. 6.

${ }^{20}$ Ibid., p. 5.
} 
of Foucault's use of the collective masculine noun "les hommes."

Foucault's celebration of the heroic in Kant's text is most visibly present in his misreading of Kant's motto sapere aude, (8:35) which means "dare to know," and which serves in Kant's text to embolden the process of individuation. In invoking this motto, however, Foucault actually reverses Kant's syntax to read aude sapere. This blind switching thus foregrounds and valorizes audacity over knowledge, while the Kantian text foregrounds the latter. In addition, Foucault translates the term as "aie le courage, l'audace de savoir. ${ }^{.21}$ In doing so, he offers two glosses for aude, thus doubling its textual thrust.

Using Baudelaire as a pivotal example, Foucault characterizes "l'attitude de modernité" as "la discontinuité du temps: rupture de la tradition, sentiment de la nouveauté. ${ }^{\text {"22 }}$ In general, Foucault's conception of modernity displays traces of resistance to relativity and phenomenology: "La modernité n'est pas un fait de sensibilité au présent fugitif; c'est une volonté d' "héroiser"le présent." It is characterized as "l'attitude qui permet de saisir ce qu'il y a d' "héroïque" dans le moment présent. ${ }^{\text {n23 }}$ A characterization of modernity of the hero who seizes the permanent in the fleeting present is replete with fictions of a masculine transcendence and resistance of the transitory present. It actualizes

\footnotetext{
un mode de rapport [au présent] qu'il faut établir à soi-méme ...un ascétisme indispensable. Eure moderne: ce n'est pas s'accepter soi-même tel qu'on est dans le flux des moments qui passent ... l'homme modeme '...est celui qui cherche à s'inventer lui-meme. ${ }^{24}$
}

This quest to find the eternal (self) in the present consists in "ressaisir quelque chose d'éternel qui n'est pas au delà de l'instant présent, ni derrière lui, mais en lui." 25

Foucault's definition is problematized further by his characterization of the modern idiom of inquiry as "un type d'interrogation

\footnotetext{
${ }^{21}$ Ibid., p. 5.

${ }^{22}$ lbid., p. 12.

${ }^{23}$ Ibid., P. 12.

24lbid., pp. 14-15.

${ }^{25}$ Ibid., p. 12.
} 
philosophique qui problématise ... la constitution de soi-même comme sujet autonome. ${ }^{\text {} 26}$ He states this in a context that valorizes audacity, autonomy, isolation and protection of the published scholarly sphere, and social stratification. He thus celebrates the text as the incipient moment and monument of a "heroic" modernity that is transmitted diachronically from Kant to Baudelaire and ultimately to Foucault himself. Operating in the same manner that he attributes to his enlightened forefather, Foucault situates himself discrètement at the receiving end of this patrilineal tradition by saying that "cette critique n'est pas transcendantale, et n'a pas pour fin de rendre possible une métaphysique: elle est ...archéologique." ${ }^{27}$ Foucault did not, however, proceed archaeologically in his own reading of Kant. I would like to demonstrate here a possible archaeological inquiry that reconstructs a discourse of power based on masculinist textual traces.

When Kant, in the essay on (un)enlightenment, says that women are unenlightened, he refers to them as "das ganze schöne Geschlecht" (8:35), using a phrase to be located between the initial characterization of unenlightenment as a state of "Faulheit" and "Feigheit" (8:35) and of the description of the unenlightened as "Hausvieh" who are confined in a "Gängelwagen" (8:35). The term "das ganze schöne Geschlecht" (8:35) is exactly the same phrase that begins the third section of the Beobachtungen über das Gefuhl des Schönen und Erhabenen (2:205-256) (1764), in which Kant bifurcates beauty and sublimeness along the lines of femininity and masculinity respectively. The feminine is beautiful, but the masculine is sublime. The inroads of this gendered discourse also lead to the section of the Anthropology entitled "Der Charakter des Geschlechts" (7:303-311), often cited in feminist critiques of Kant, but yet to be read for its examples of mechanisms of displacement and denial within its patriarchal project.

This text configures woman as the dominator who is to be distrusted. At home she holds a "Regiment" (7:304) and wages domestic war with her tongue ("den Hauskrieg mit der Zunge") (7:304). The positing of woman as the aggressor thus vindicates male domination. He has "das Recht des Stärkeren" (7:304) and the right to use his strength, because woman can render him entwaffnet and wehrlos. Thus, in preemptive defense, he assumes the dominating position. Otherwise, she will act out her agenda, which is the conquest of the entire male species ("die Eroberung des ganzen Geschlechts") (7:305).

\footnotetext{
${ }^{26}$ Ibid., p. 16.

${ }^{27}$ Ibid., p. 20.
} 
It is precisely in this representation of woman, however, that the voices of democracy and misogyny collide. Oppressive urges become themselves repressed by the censorship of a democratic morality and transformed into euphemized justifications of hierarchical order:

Wer soll dann den oberen Befehl im Hause haben? ... Die Frau soll herrschen und der Mann regieren; denn die Neigung herrscht, und der Verstand regiert.

This is a clear attempt to invoke egalitarian discourse in order to repackage the hierarchical relationship in a form that simultaneously validates but does not embarrass male dominance. Here a primitive master/slave dyad is reprocessed for bourgeois consumption. The transformation consists in displacing the problem into politological discourse and then denying dominance and servitude by affirming their opposite - egalitarianism. The inversion allows the primitive dynamic to slip in undercover, detected subliminally but not superficially.

A similar occasion of communication via displacement and denial is found in a gratuitous anecdote that is ostensibly intended to illustrate the function of jealousy. The anecdote appears as a footnote and requires closer scrutiny:

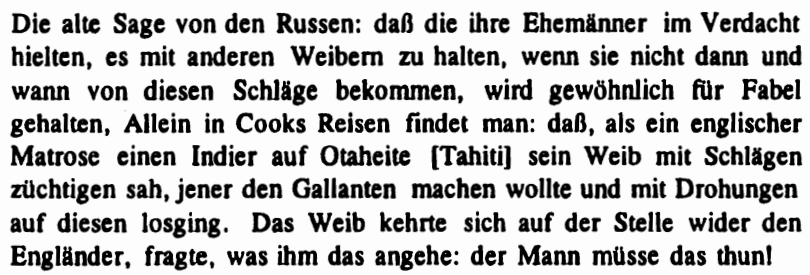

(7:304)

The dynamics of this passage as well as the semiotics of its marginalized situation as a footnote effect an intricate solution to the problem of communicating spouse abuse affirmatively to the male German reader. This is not only distanced from the center of discourse, but it is also transformed into a joke.

In Der Witz und seine Beziehung zum Unbewußten, ${ }^{28}$ Freud demonstrated that the technique of jokes is triadic in nature. It involves

\footnotetext{
${ }^{28}$ Sigmund Freud, Der Witz und seine Beziehung zum Unbewußten, in Studienausgabe, 10 Bände (Frankfurt: Fischer, 1982), 6:9-219.
} 
a narrator, an audience, and a third person object at the expense of whom the joke is told. Communication between narrator and audience presupposes an implicit shared hostile attitude toward the outsider that is subject to mechanisms of guilt, censorship, and repression. The pleasure of the joke is gained through the lifting of censorship by the techniques of displacement and condensation.

The joke at hand is configured in a dialogue between the narrator and a projected male German audience whose shared hostility toward the feminine is checked by socio-political codes of gentlemanliness and egalitarianism. The repression involved evokes primitive reactive mechanisms of tension reduction by physical force. These urges must be expressed, however, in a way that is sufficiently transformed so as to escape censorship. It is the swift and unnoticed escape that catalyzes the pleasurable reaction.

The dissimulating transformations here involve interpolations of displacement and denial. The point of departure of the displacement from Germans to Russians is itself a denial: we do not do this; the Russians do. The displacement is then followed by another denial: the Russians do not really do this either; it is merely a myth. Russia thus offers a convenient metonym for the displacement. The next displacement, in which the affirmation is to emerge, is to India, further along horizontally and, on a Eurocentric scale of civilization, vertically further down on the metonymic chain of substitutions.

The ultimate outsider here is the repressive ethical code that checks masculinist violence. The feminine is represented as the appropriated other, as property common to the male narrator and audience. The juxtaposition of two cultures constitutes the possibility of disjuncture and of comic reversal of expectation. The English gentleman, precoded for a Western sense of propriety, becomes the fool who is fooled by the appearance of impropriety. The comic moment expels the ethical censor, diffuses censorship, and validates male hostility by introducing the desired figure of the masochistic woman.

In his misreading of Kant, Foucault ultimately becomes himself an object of scrutiny if we apply to him his own system of unmasking ideologies. He writes a fiction of a diachronic intellectual in heritance of "great" ideas and suppresses recognition that these ideas (e.g. autonomy, disconnectedness, transcendence of history and a superordinate view thereof) had already been subject to the critique of some feminist 
theorists. $^{29}$ In Foucault, one cognitive paradigm actually involves the passing on of "heroic" ideas from fathers to sons - a subliminal fiction that history is made by great autonomous men.

This is Foucault's Fourth Critique, that ostensibly "doit se détourner de tous ces projets qui prétendent être globaux et radicaux, ${ }^{n 30}$ but which clearly itself succumbs to totalizing diachronic structures. This critique, we are told, should ask, "comment nous sommes-nous constitués comme sujets de notre savoir; comment nous sommes-nous constitués comme sujets qui exercent ou subissent des relations de pouvoir, ${ }^{n 1}$ yet his own cognitive repression produces a power-oriented misreading that leaves Kant's masculinist discourses of power and binary oppositions unread and belies Foucault's own project of "un travail d'enquêtes diverses, ${ }^{\text {"32 }}$ which now appears instead to be "une quête héroïque."

The University of Richmond

THOMAS PAUL BONFIGLIO

${ }^{29} \mathrm{cf}$. Nancy Chodorow, The Reproduction of Mothering(Berkeley: University of Califomia Press, 1978).

${ }^{30}$ Foucault, p. 21.

"Ibid., p. 25.

${ }^{32}$ Ibid., p. 26. 